\title{
Pengaruh Pembatasan Sosial sebagai Upaya Menekan Penularan Covid-19 terhadap Kondisi Kesehatan Mental Remaja: Literature Review
}

\author{
Dita Riski Khasanah ${ }^{1}$, Hennanda Annastya Annisa Indarko ${ }^{1}{ }^{\square}$, Ida Rosilawati ${ }^{1}$, Dwi Sarwani Sri Rejeki ${ }^{1}$ \\ ${ }^{1}$ Fakultas Ilmu-Ilmu Kesehatan, Universitas Jenderal Soedirman
}

\author{
Info Artikel \\ Diterima 16 Juni 2021 \\ Disetujui 30 November 2021 \\ Diterbitkan 31 Desember 2021
}

\section{Kata Kunci:}

Pembatasan Sosial, Remaja,

Gangguan Kesehatan Mental

e-ISSN:

2613-9219

Akreditasi Nasional:

Sinta 4
Keywords:

Social Restrictions,

Adolescents, Mental Health

Problems

\section{$\square^{\square}$ Coresponding author: \\ hennanda.indarko@mhs.unsoed.ac.id}

\begin{abstract}
Abstrak
Latar Belakang: Hingga akhir Juni 2021, kejadian Covid-19 di Indonesia telah mencapai 1,64 juta kasus dan 44.500 kematian. Kebijakan pembatasan sosial merupakan upaya untuk pemerintah menekan laju penularan Covid-19 meskipun disisi lain, kebijakan ini juga memunculkan ketakutan, kecemasan, dan kekhawatiran masyarakat termasuk remaja. Pengembangan emosional dan perilaku remaja menuju dewasa memerlukan ruang bersosialisasi, namun terkendala oleh pembatasan sosial. Tujuan: mengetahui pengaruh pembatasan sosial terhadap kesehatan mental remaja. Metode: penelitian ini menggunakan metode literature review tahun 2019 sampai 2021 yang didapat dari database Google Scholar, PubMed, dan Science Direct dengan menggunakan kata kunci pembatasan sosial, remaja, gangguan kesehatan mental, Youth and Children, Covid-19, Impact, dan mental health. Kriteria artikel yang dipilih adalah artikel terbitan 2019-2021 nasional dan intenasional yang berkaitan dengan penelitian literature review. Hasil: dampak dari adanya pembatasan sosial bagi kesehatan mental para remaja cukup bervariasi. Adanya keterbatasan dalam bersosialisasi, kejenuhan dan banyaknya tugas yang dibebankan kepada remaja menjadi faktor utama para remaja mengalami gangguan mental seperti stress, depresi, dan anxiety. Kesimpulan: pembatasan sosial secara tidak langsung memiliki dampak pada kesehatan mental remaja dan bahkan memicu gangguan kesehatan mental pada remaja.
\end{abstract}

\begin{abstract}
Background: At the end of June 2021, the occurrence of Covid-19 in Indonesia has reached 1.64 million cases and 44,500 deaths. The social restriction policy is an effort for the government to suppress the rate of transmission of Covid-19, although on the other hand, this policy also raises fear, anxiety, and worry for the community, including teenagers. The emotional development and behaviour of adolescents towards adulthood require social space, but are constrained by social restrictions. Objective: to determine the effect of social restrictions on adolescent mental health. Methods: This study uses a literature review method from 2019 to 2021 obtained from the Google Scholar, PubMed, and Science Direct databases using the keywords social restrictions, youth, mental health disorders, Youth and Children, Covid-19, Impact, and mental health. . The criteria for the selected articles were articles published in 2019-2021 nationally and internationally related to literature review research. Results: the impact of social restrictions on the mental health of adolescents is quite varied. The existence of limitations in socializing, boredom and the many tasks assigned to adolescents are the main factors for adolescents experiencing mental disorders such as stress, depression, and anxiety. Conclusion: social restrictions indirectly have an impact on the mental health of adolescents and even trigger mental health disorders in adolescents.
\end{abstract}

(C) 2021 Program Studi S-1 Kesehatan Masyarakat Universitas Muhammadiyah Semarang 


\section{Pendahuluan}

Covid-19 kini bukanlah sesuatu yang asing lagi di kalangan masyarakat. Kasusnya yang hingga kini masih belum usai bisa dikatakan "awet", pasalnya sudah lebih dari satu tahun kasusnya bertahan dan masih ada kemungkinan adanya masyarakat terinfeksi Covid-19. WHO pada 11 Maret 2020 mengumumkan Covid-19 sebagai pandemi di seluruh dunia dan menjadi penyebab kematian nomor satu di seluruh dunia [1]. Penyebaran virus Covid-19 diketahui melalui droplet saliva atau cairan yang keluar dari hidung orang yang terinfeksi, dimana orang tersebut batuk atau bersin dan droplet menempel pada benda atau pada orang yang tidak terinfeksi Covid-19 [2].

Sampai dengan bulan Juni 2021, kasus terkonfirmasi Covid-19 diseluruh dunia terdapat 147 juta kasus dengan 3,1 juta kematian. Sedangkan kasus terkonfirmasi positif Covid-19 di Indonesia terdapat sebanyak 1,64 juta dengan 44.500 kematian akibat Covid-19 [3]. Dengan adanya fakta tersebut, Covid-19 jelas memiliki dampak di bidang kesehatan, sehingga diperlukan suatu usaha yang efektif untuk menekan penularan Covid-19.

Lockdown merupakan salah satu langkah yang ditempuh untuk menekan penularan Covid-19 dengan cara membatasi adanya kegiatan sosial di tengah masyarakat. Di Indonesia lockdown tidak dilakukan di seluruh daerah melainkan hanya di daerah dengan peningkatan penularan Covid-19 yang tinggi. Sebagai gantinya dilakukan. Pembatasan Sosial Berskala Besar (PSBB) [4]. Di dalam aturan PSBB ini, masyarakat diperintahkan untuk tetap dirumah, kecuali untuk urusan yang sangat mendesak. Upaya ini telah mengubah kebiasaan aktivitas sosial masyarakat yang sebelumnya dilakukan secara offline atau secara langsung berubah menjadi aktivitas online.

Lockdown secara signifikan telah berhasil menekan angka kasus Covid-19 pada beberapa negara seperti Italia, Paris, dan Cina. Namun, berbeda dengan Indonesia yang memberlakukan peraturan PSBB, dimana kasus Covid-19 masih mengalami peningkatan bersifat "lambat", karena disinyalir banyak masyarakat di beberapa daerah yang tidak patuh akan protokol kesehatan dan melakukan PSBB dengan berada dirumah saja. Oleh karena ketidak patuhan ini, pada beberapa daerah tersebut dilakukan lockdown.

Setelah dilakukannya upaya pembatasan sosial, khususnya di Indonesia, dampak Covid-19 justru semakin meluas keseluruh aspek kehidupan masyarakat, yaitu aspek ekonomi, sosial, dan pendidikan. Situasi ini menyebabkan kecemasan di tengah masyarakat meningkat, hingga menimbulkan adanya gangguan kesehatan mental seperti stress, insomnia, penolakan, dan ketakutan, serta gejala depresi [5]. Hal ini pun dirasakan oleh kalangan remaja dan juga anak-anak, mulai dari siswa Sekolah Dasar hingga mahasiswa. Dengan diberlakukannya upaya pembelajaran melalui daring atau online di tengah pembatasan sosial oleh Kemendikbud menyebabkan adanya ketidakpastian baik pada tenaga pendidik, orang tua, murid, atau siswa hingga mahasiswa serta teknologi yang mendukung antara pihak-pihak tersebut. Hal tersebut membuat kegiatan belajar mengajar menimbulkan efek kebosanan, tidak menyenangkan, hingga kekhawatiran dan ketidak percaya dirian pada remaja karena minimnya ruang berinteraksi dengan teman dan juga tenaga pendidik [6].

Remaja termasuk ke dalam generasi milenial yang memiliki semangat menjajaki dunia luar, mereka berada di tahapan pengembangan emosional dan perilaku karena berada pada masa peralihan menuju dewasa. Remaja mengalami perubahan baik secara biologis, psikologis, dan social [6]. Mereka cenderung senang berinteraksi dengan lingkungan sosial di luar rumah. Dengan fakta ini, pembatasan sosial tentu saja menjadi tantangan yang besar bagi remaja dalam perjalanan mereka menuju pendewasaan, sehingga tidak sedikit remaja dengan kasus gangguan mental di tengah pandemi dan pembatasan sosial ini.

Gangguan kesehatan mental pada remaja berdampak pada penyesuaian diri yang buruk di lingkungan sosial, pengurangan daya konsentrasi, dan terjadinya penurunan prestasi [5]. Fakta tersebut membuktikan bahwa terdapat hubungan antara pandemi Covid-19 dan pembatasan sosial terhadap gangguan kesehatan mental pada remaja secara negatif yang perlu dikaji untuk selanjutnya dijadikan sebagai bahan literatur agar dapat dicapai suatu upaya yang lebih baik di masa depan dalam menghadapi masalah serupa.

\section{Metode}

Pada penelitian ini, penulis menggunakan metode literatur review. Literatur review adalah sebuah metodologi penelitian yang bertujuan untuk mengumpulkan dan mengambil intisari dari penelitian sebelumnya serta menganalisis beberapa overview para ahli yang tertulis dalam teks [7].

1. Pertanyaan panduan: Apakah pembatasan sosial mempengaruhi kesehatan mental pada remaja? Kata kunci dalam Bahasa indonesia: pembatasan sosial, remaja, dan gangguan kesehatan mental

2. Kriteria inklusi: dipilih artikel dengan judul dan isi yang relevan dengan tujuan penelitian yang akan dilakukan, berbahasa indonesia, dan fulltext, 
artikel penelitian yang dipublikasikan pada tahun 2019-2021. Kriteria eksklusi: artikel tidak memiliki struktur lengkap dan tidak membahas tentang pembatasan sosial atau gangguan kesehatan mental.

3. Data diperoleh dari database elektronik yaitu Google Scholar, PubMed, dan Science Direct yang diterbitkan antara tahun 2019-2021. Kata kunci yang digunakan pada Google Scholar, yaitu pembatasan sosial, remaja, gangguan kesehatan mental, sementara untuk PubMed dan Science Direct menggunakan kata kunci Covid-19, impact, anxiety and depressi, mental health, dan youth and children. Temuan artikel pada database sebanyak 8.870 artikel, dan kemudian dipilih 25 artikel yang memenuhi syarat memiliki keterkaitan dengan penelitian, melalui pembacaan judul dan abstrak. Setelah pembacaan lengkap pada artikel, ditetapkan 7 artikel yang dianalisa pada penelitian ini.

4. Masing-masing dari 7 artikel yang dipilih untuk dibaca dengan cermat dari abstrak, tujuan, data analisis dari pertanyaan awal peneliti untuk mengumpulkan informasi mengenai pengaruh pembatasan sosial terhadap kesehatan mental remaja.

\section{Gambar 1}

Proses Literature Review

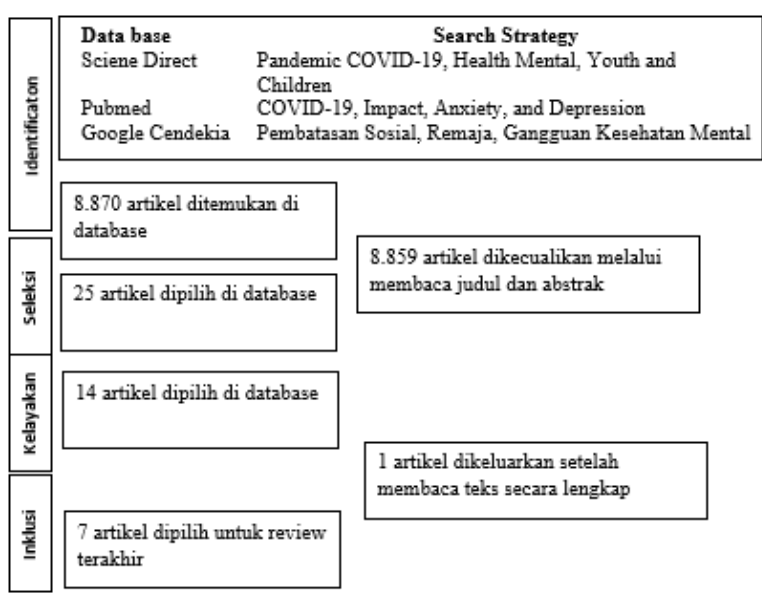

\section{Hasil}

Artikel yang digunakan dalam studi literatur ini terdapat 7 artikel yang dipilih baik dari Indonesia ataupun Internasional, artikel tersebut diterbitkan dalam rentang waktu 2019 sampai 2021. Masing-masing artikel dibaca dengan cermat dari abstrak, tujuan, analisis data untuk pengumpulan informasi, hingga hasil dan pembahasan serta kesimpulan. Studi literatur artikel pada penelitian ini membahas tentang dampak pembatasan sosial terhadap gangguan kesehatan mental.
Pembatasan sosial menjadi salah satu penyebab gangguan kesehatan mental pada masyarakat khususnya remaja, yaitu individu yang sedang menempuh masa pendewasaan yang memerlukan lingkungan sosial yang luas. 7 artikel yang dipilih merupakan artikel yang sesuai dengan kriteria inklusi dan eksklusi pada penelitian ini. Ringkasan hasil artikel yang direview dapat dilihat pada tabel 1 .

SARS Cov2 sebagai penyebab Covid-19 sangat mudah menyebar dan menular dari satu individu ke individu lainnya. Covid-19 ditularkan melalui cairan saliva dari penderita saat penderita batuk atau bersin ataupun melalui virus yang menempel pada benda disekitar [2]. Ketahanan hidup virus corona dalam benda dan udara juga diketahui cukup lama sehingga dapat menyebabkan banyaknya penularan terhadap individu yang belum terinfeksi Covid-19. Oleh karena itu, pemerintah menciptakan berbagai kebijakan dan program dalam upaya penekanan angka penularan Covid-19. "Pembatasan Sosial" menjadi salah satu dari banyak kebijakan yang dijalankan pemerintah Indonesia dalam upaya menekan penularan Covid-19. Kegiatan pembatasan sosial dalam suatu wilayah yang terdampak wabah virus corona perlu dilakukan sebagai upaya meminimalisir penyebaran wabah virus tersebut [8].

Kebijakan ini membawa harapan pada pemutusan mata rantai penyebaran Covid-19. Meskipun tidak sepenuhnya pembatasan sosial dijalankan, banyak kegiatan di berbagai bidang yang terdampak oleh kebijakan ini. Pada bidang ekonomi misalnya, terjadi kelumpuhan aktivitas perkantoran serta kegiatan dialihkan menjadi Work From Home (WFH), penurunan produktivitas pasar dan ekonomi, serta banyak orang kehilangan pekerjaan. Dilansir dari laman berita Tempo, Kemenaker melaporkan setidaknya ada 3,05 juta orang pekerja terdampak Covid-19 per 2 Juni 2020 [9]. Di bidang transportasi, terjadi kemacetan arus layanan transportasi umum sejalan dengan penutupan maupun pembatasan bandara, stasiun, bahkan terminal bus. Di bidang pariwisata, objek - objek yang telah banyak digarap sebagai persiapan pendongkrak ekonomi justru lesu dan terbengkalai. Begitu pula pada bidang pendidikan, yang mana metode pembelajaran dialihkan menjadi daring. Meskipun hal tersebut demi kebaikan masyarakat secara umum, tetapi turut menimbulkan masalah baru.

Hasil penelitian menunjukkan bahwa pembelajaran daring mempengaruhi stress akademik selama pandemi covid-19 [10]. Keadaan yang mengharuskan siswa maupun mahasiswa untuk tetap di dalam rumah dan mengikuti pembelajaran secara daring menjadikan mereka mengalami kejenuhan, kurang 
bersosialisasi, dan masalah psikologis lainnya karena tuntutan beradaptasi secara mendadak pada keadaan yang jauh berbeda. Belum lagi keterbatasan sarana dan prasarana yang dialami oleh sebagian mahasiswa dan pelajar. Seperti minimnya akses internet, media pembelajaran yang belum siap, tidak memiliki perangkat yang memadai, dan keterbatasan penguasaan teknologi. Pembelajaran daring dan kemampuan pelajar dalam menggunakan teknologi memiliki hubungan yang signifikan terhadap kesehatan mental [11].

Walaupun dengan keadaan yang berbeda, tugas yang dibebankan kepada mahasiswa dan pelajar tetap sama, bahkan dirasa lebih berat karena pencarian referensi terbatas pada internet saja. Kondisi ini akan membuat tekanan psikologis bagi para pelajar.

\section{Pembahasan}

Penelitian di dua perguruan tinggi di Jawa Barat tahun 2020 menunjukan mahasiswa yang mengalami kesulitan tidur karena dampak tugas ini sekitar 60\%. Penelitian menunjukkan bahwa tingkat anxiety atau kecemasan remaja pada masa pandemic Covid-19 berada pada kategori tinggi [12].

Covid-19 telah mengancam kesehatan fisik dan psikis, serta cara hidup sehari-hari. Secara tidak sengaja, setiap hari pelajar dan mahasiswa terus mendengar berbagai berita hingga kemudian memikirkan berbagai cara untuk melindungi diri dari virus. Pada kondisi demikian, mahasiswa dan pelajar juga dituntut harus tetap fokus untuk belajar. Akibat pemberitaan Covid-19, pikiran menjadi tidak fokus dan sulit berkonsentrasi pada pelajaran [13]. Bahkan perhatian terhadap pemberitaan Covid-19 yang menyatakan Covid-19 sebagai penyakit berbahaya dan mematikan menjadi inti dari timbulnya anxiety masyarakat termasuk remaja [1]. Sering lupa juga merupakan salah satu dampak dari anxiety. Alexandra Parpura, ahli gerontologi dan pendiri Aging Perspectives di Chevy Chase menjelaskan bahwa anxiety dapat mempengaruhi memori ingatan, meningkatkan iritabilitas dan dapat merubah emosi remaja seperti mudah marah. Anxiety yang dialami tiap orang berbeda-beda, tentu saja hal ini berkontribusi terhadap iritabilitas dan kemarahan. Penelitian menunjukkan bahwa anxiety juga dapat memicu emosi ini [13].

Faktor risiko gangguan kesehatan mental pada remaja di Indonesia yang terjadi karena pengaruh pembatasan sosial sangat bervariasi. Kurangnya bersosialisasi dengan teman sebaya, adanya kejenuhan karena hampir sepanjang waktu berada di rumah, banyaknya tugas yang ditanggung, kurangnya informasi dalam pembelajaran, kesulitan dalam mengakses internet, infrastruktur yang kurang memadai seperti tidak memiliki laptop atau handphone, masalah ekonomi di keluarga, serta kesulitan dalam memahami pelajaran dari jarak jauh, menjadi faktor resiko gangguan kesehatan mental pada remaja di Indonesia yang menyebabkan mereka menjadi stress, lesu, hingga depresi. Gangguan pembelajaran berskala besar ini menimbulkan konsekuensi yang berat terhadap mental remaja. Pembebanan tugas yang dikemas dengan kurang kreatif menjadi penghambat pemahaman siswa dan berpotensi pada terjadinya gangguang mental seperti stres dan anxiety [14]. Kejadian ini menjadi salah satu faktor pendukung mengapa pembelajaran online mengakibatkan gangguan kesehatan mental pada remaja terjadi.

Selain disebabkan karena diberlakukannya pembelajaran daring, gangguan kesehatan mental pada remaja seperti timbulnya depresi dikarenakan remaja kehilangan ruang sosial untuk beraktivitas. Jika kejadian ini berlangsung cukup lama maka akan menyebabkan dampak buruk seperti timbulnya depresi, anhedonia, menarik diri dari kehidupan sosial, dan kehilangan semangat hidup yang merujuk pada gangguan kesehatan mental [5].

Anak muda merupakan aktor penting di dalam kemajuan bangsanya. Namun, bagaimana jika banyak ditemukan remaja mengalami gangguan mental. Hal ini akan menjadi permasalahan krusial yang perlu segera ditindaklanjuti penyelesaiannya. Ada beberapa cara penyelesaian untuk mengurangi faktor stress atau gangguan mental lainnya. Namun, hal ini juga butuh kesadaran diri dari remaja tersebut dan kerja sama dari pihak keluarga, lingkungan sekitar, maupun pemerintah.

Selain penggunaan teknologi, para remaja bisa melakukan kegiatan produktif di dalam rumah dengan membaca novel atau buku yang berkaitan dengan pembangkit motivasi hidup mereka. Di sela-sela mengerjakan tugas juga perlu istirahat yang cukup dan menenangkan pikiran dengan mendengarkan musik kesukaan mereka ataupun melakukan jogging pada pagi hari bersama keluarga dengan tetap melaksanakan protokol kesehatan.

WHO, UNICEF, Global Partnership to End Violence, Centers for Disease Control, the United States Agency for International Development (USAID), dan mitra telah merilis tips pengasuhan sehat selama pandemi Covid-19 untuk membantu orang tua membangun interaksi yang positif dengan anak-anak mereka selama masa isolasi pandemi Covid-19. Selain itu, World Movement juga mengadakan jambore online yang menjangkau ribuan anak muda agar mereka bisa ikut berpartisipasi dalam seminar online, kegiatan 
perawatan diri, dan tanya jawab [15]. Selanjutnya Pemerintah Indonesia juga tetap harus memantau perkembangan kegiatan pembelajaran di sekolahsekolah hingga ke perguruan tinggi untuk menilai apakah sistem pembelajaran terlaksana dengan baik, apakah pemberian tugas atau PR selama online ini akan membebankan para pelajar atau tidak. Dari survei tersebut akan terjalin komunikasi yang baik antara pemerintah dengan tenaga pendidik serta dapat membuat suatu terobosan program baru untuk mengatasi permasalahan gangguan mental pada remaja di Indonesia.

\section{Kesimpulan}

Pembatasan sosial sebagai upaya menekan penularan Covid-19 juga memicu masalah lain, yaitu gangguan kesehatan mental, khususnya pada remaja. Pembelajaran daring menyebabkan timbulnya perasaan anxiety, depresi, dan stress. Faktor pemicunya adalah keterbatasan jaringan, teknologi, dan pengetahuan penggunaan teknologi pada pelajar. Beban tugas dan cara pembelajaran daring dilakukan juga menjadi faktor pemicu stress dan depresi.

Penataan ulang kebijakan pendidikan di masa pandemi dengan pembelajaran tatap muka yang menerapkan protokol kesehatan secara ketat bagi pelajar, tenaga pendidik, dan tokoh lain pada institusi pendidikan perlu diterapkan, disamping vaksinasi Covid-19 bagi seluruh individu di institusi pendidikan Pemenuhan kondisi ini dapat memberi ruang sosial pada remaja dan meminimalkan anxiety, depresi, dan stres.

\section{Daftar Pustaka}

[1] D. Cucinotta and M. Vanelli, "WHO declares COVID-19 a pandemic," Acta Biomedica, vol. 91, no. 1. pp. 157-160, 2020, doi: 10.23750/abm.v91i1.9397.

[2] WHO, "Coronavirus," Health Topics, 2020. .

[3] W. \& J. CSSE, “Data Covid-19," 2021. https://www.google.com/search?safe=strict\&rl z=1C1GCEB_enID896ID896\&q=DATA+CO VID+19\&spell=1\&sa=X\&ved=2ahUKEwislo7 g0ZnwAhXEbn0KHbCuCS4QBSgAegQIARA $\mathrm{x}$.

[4] KemenkesRI, "Peraturan Menteri Kesehatan Republik Indonesia Nomor 9 Tahun 2020 tentang Pedoman Pembatasan Sosial Berskala Besar dalam Rangka Percepatan Penanganan Corona Virus Disease 2019 (Covid-19," 2020.

[5] D. Courtney, P. Watson, M. Battaglia, B. H. Mulsant, and P. Szatmari, “COVID-19 Impacts on Child and Youth Anxiety and Depression: Challenges and Opportunities," Can. J. Psychiatry, vol. 65, no. 10, pp. 688-691, 2020, doi: $10.1177 / 0706743720935646$.

[6] S. Winurini, "Pengaruh pandemi covid-19 terhadap kesehatan jiwa remaja," 2021.

[7] H. Snyder, "literature Review As a Research Methodology: An Overview and Guidelines," J. Bussiness Res., vol. 104, pp. 333-339, 2019.

[8] N. R. Yunus and A. Rezki, "Kebijakan Pemberlakuan Lock Down Sebagai Antisipasi Penyebaran Corona Virus Covid-19," SALAM J. Sos. dan Budaya Syar-i, vol. 7, no. 3, pp. 227238, 2020, doi: 10.15408/sjsbs.v7i3.15083.

[9] D. R. Cahyani, "Dampak Corona, 3,05 Juta Orang Terkena PHK Hingga Juni," Tempo.co, 2020. .

[10] E. Andiarna, Funsu; Kusumawati, "Effects of Online Learning on Student Academic Stress During the Covid-19 Pandemic," J. Psikol., vol. 16, no. 2, pp. 139-150, 2020.

[11] N. Gustantia Annisa et al., "Hubungan Sistem Pembelajaran Daring dengan Kesehatan Mental Mahasiswa Di Era COVID-19 Menggunakan Chi-Square Test dan Dependency Degree," Semin. Nas. Teknol. Inf. Komun. dan Ind., vol. 0, no. SNTIKI, pp. 2579-5406, 2020, [Online]. Available: http://ejournal.uinsuska.ac.id/index.php/SNTIKI/article/view/111 97.

[12] L. Fitria and I. Ifdil, "Kecemasan remaja pada masa pandemi Covid -19," J. Educ. J. Pendidik. Indones., vol. 6, no. 1, p. 1, 2020, doi: $10.29210 / 120202592$.

[13] Muyasaroh. et al., "Kajian Jenis Kecemasan Masyarakat Cilacap dalam Menghadapi Pandemi Covid-19. Lembaga Penelitian dan Pengabdian Masyarakat (LP2M) Universitas Nahdlatul Ulama Al Ghazali (Unugha) Cilacap," 2020.

[14] M. P. Wulansari, "Impresi Teknis Penugasan terhadap Beban Tugas Siswa dalam Pembelajaran Daring di Madarasah Aliyah Negeri 1 Nganjuk," ISLAMIKA, vol. 3, no. 2, pp. 149-162, 2021, doi: 10.36088/islamika.v3i2.1242.

[15] UNICEF, "Bekerja dengan dan untuk anak muda COVID-19: Bekerja dengan dan untuk anak muda," 2020. 
TABEL 1

Daftar Literature Review Jurnal

\begin{tabular}{|c|c|c|c|c|c|c|c|c|c|}
\hline No & Penulis & Judul Artikel & Negara & Tujuan & Desain & Sampel & Prosedur & Aspek Mental & Hasil \\
\hline 1 & $\begin{array}{l}\text { N. R. Yunus } \\
\text { dan A. Rezki } \\
(2020)\end{array}$ & $\begin{array}{l}\text { Kebijakan } \\
\text { Pemberlakuan } \\
\text { Lock Down } \\
\text { Sebagai } \\
\text { Antisipasi } \\
\text { Penyebaran } \\
\text { Corona Virus } \\
\text { Covid-19 }\end{array}$ & Indonesia & 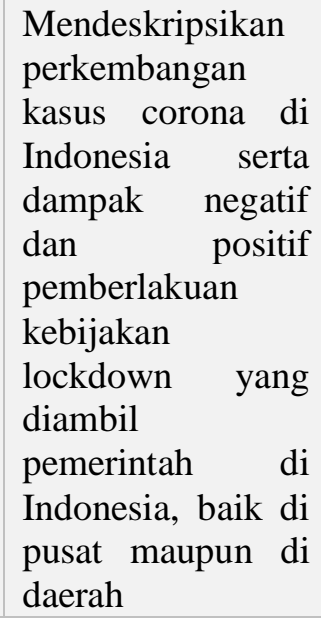 & $\begin{array}{l}\text { Metode } \\
\text { kualitatif } \\
\text { dengan } \\
\text { pendekatan } \\
\text { literatur cross } \\
\text { sectional }\end{array}$ & - & $\begin{array}{l}\text { Pendekatan hukum } \\
\text { dengan meninjau UU No. } \\
6 \text { tahun } 2018 \text { tentang } \\
\text { kekarantinaan kesehatan, } \\
\text { Seruan Gubernur DKI } \\
\text { Jakarta No. } 5 \text { tahun 2020, } \\
\text { Fatwa Majelis Ulama } \\
\text { Indonesia, dan pendekatan } \\
\text { kasus wabah virus corona } \\
\text { di masyarakat }\end{array}$ & - & $\begin{array}{l}\text { Kegiatan lockdown } \\
\text { dalam suatu wilayah } \\
\text { yang terdampak wabah } \\
\text { virus corona perlu } \\
\text { dilakukan sebagai upaya } \\
\text { meminimalisir } \\
\text { penyebaran virus } \\
\text { tersebut. Walau pun } \\
\text { tentunya menimbulkan } \\
\text { dampak negatif yang } \\
\text { beresiko pada tatanan } \\
\text { perekonomian negara. }\end{array}$ \\
\hline 2 & $\begin{array}{l}\text { N. Gustantia } \\
\text { Annisa et al } \\
\text { (2020) }\end{array}$ & $\begin{array}{l}\text { Hubungan } \\
\text { Sistem } \\
\text { Pembelajaran } \\
\text { Daring } \\
\text { dengan } \\
\text { Kesehatan } \\
\text { Mental } \\
\text { Mahasiswa Di } \\
\text { Era COVID- } \\
19 \\
\text { Menggunakan } \\
\text { Chi-Square } \\
\text { Test dan } \\
\text { Dependency } \\
\text { Degree }\end{array}$ & Indonesia & $\begin{array}{l}\text { Mengetahui } \\
\text { hubungan dan nilai } \\
\text { ketergantungan } \\
\text { atribut antara } \\
\text { sistem } \\
\text { pembelajaran } \\
\text { daring terhadap } \\
\text { kesehatan mental } \\
\text { mahasiswa selama } \\
\text { masa pendemi } \\
\text { Covid-19 }\end{array}$ & $\begin{array}{l}\text { Cross } \\
\text { Sectional }\end{array}$ & $\begin{array}{l}\mathrm{N}=32 \\
\text { Mahasiswa }\end{array}$ & 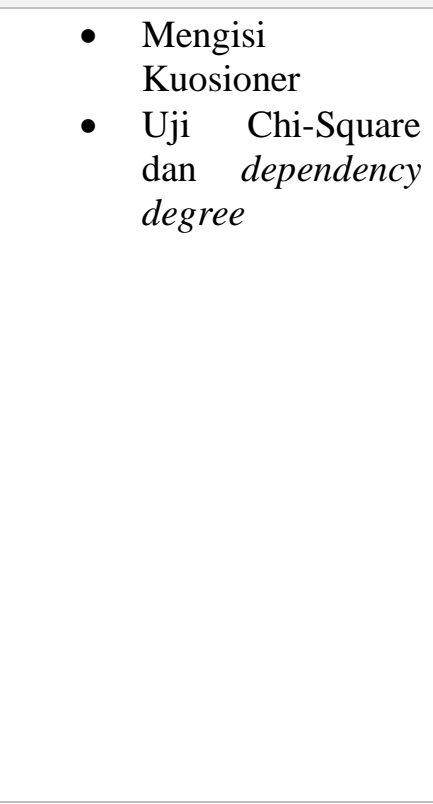 & Gejala PTSD & 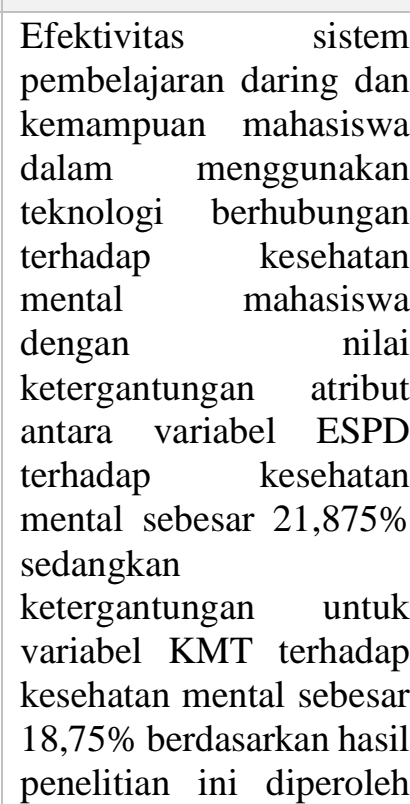 \\
\hline
\end{tabular}




\begin{tabular}{|c|c|c|c|c|c|c|c|c|c|}
\hline No & Penulis & Judul Artikel & Negara & Tujuan & Desain & Sampel & Prosedur & Aspek Mental & Hasil \\
\hline & & & & & & & & & $\begin{array}{l}\text { gambaran bahwa dari } 32 \\
\text { mahasiswa } 12.15 \% \\
\text { memiliki gejala PTSD } \\
\text { Parsial, 84.4\% gejala } \\
\text { PTSD sedang dan } 3.1 \% \\
\text { terdiagnosa terkena } \\
\text { PTSD. }\end{array}$ \\
\hline 3. & $\begin{array}{l}\text { L. Fitria dan I. } \\
\text { Ifdil (2020) }\end{array}$ & $\begin{array}{l}\text { Kecemasan } \\
\text { remaja pada } \\
\text { masa pandemi } \\
\text { Covid }-19\end{array}$ & Indonesia & $\begin{array}{l}\text { Menganalisis } \\
\text { tingkat kecemasan } \\
\text { yang dialami } \\
\text { remaja selama } \\
\text { pandemi Covid-19 }\end{array}$ & $\begin{array}{l}\text { Cross } \\
\text { Sectional }\end{array}$ & $\begin{array}{l}\mathrm{N}=139 \\
\text { Remaja } \\
(12-19 \\
\text { tahun) }\end{array}$ & $\begin{array}{l}\text { - } \begin{array}{l}\text { Mengisi kuisioner } \\
\text { - } \\
\text { dengalisis deskriptif }\end{array} \\
\text { SPSS }\end{array}$ & Anxiety & $\begin{array}{llr}\text { Tingkat } & \text { anxiety } & \text { remaja } \\
54 \% \text { berada } & \text { pada } \\
\text { kategori tinggi } & \end{array}$ \\
\hline 4. & $\begin{array}{l}\text { Muyasaroh. } \\
\text { et al (2020) }\end{array}$ & $\begin{array}{l}\text { Kajian Jenis } \\
\text { Kecemasan } \\
\text { Masyarakat } \\
\text { Cilacap dalam } \\
\text { Menghadapi } \\
\text { Pandemi } \\
\text { Covid-19 }\end{array}$ & Indonesia & $\begin{array}{lr}\text { Memetakan } & \text { jenis } \\
\text { kecemasan } & \text { yang } \\
\text { dialami } & \\
\text { masyarakat } & \text { saat } \\
\text { pandemi Covid- } \\
19 .\end{array}$ & $\begin{array}{l}\text { Cross } \\
\text { Sectional }\end{array}$ & $\begin{array}{l}\mathrm{N}=626 \\
\text { Warga } \\
\text { Cilacap }\end{array}$ & 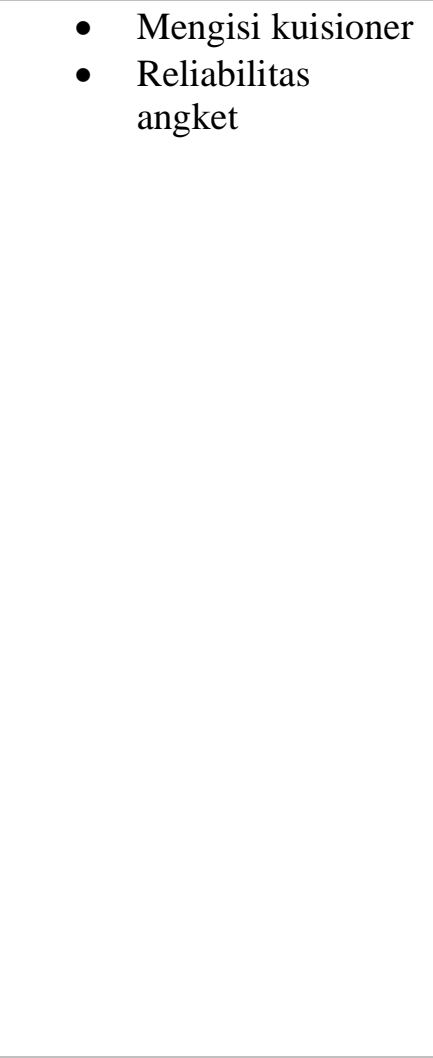 & Kecemasan & $\begin{array}{lr}\text { Sebanyak 2\% } & \text { masyarakat } \\
\text { Cilacap } & \text { mengalami } \\
\text { kecemasan } & \text { umum, } 12 \% \\
\text { kecemasan } & \text { panik, } 7 \% \\
\text { kecemasan } & \text { sosial, } 16 \% \\
\text { kecemasan } & \text { obsesif, } 1 \% \\
\text { kecemasan } & \text { umum } \\
\text { disertai } & \text { dengan } \\
\text { kecemasan } & \text { panik, } 1 \% \\
\text { kecemasan } & \text { umum } \\
\text { disertai } & \text { kecemasan } \\
\text { sosial, 0\% } & \text { kecemasan } \\
\text { umum } & \text { disertai } \\
\text { kecemasan } & \text { obsesif, } 3 \% \\
\text { keccemasan } & \text { panik } \\
\text { disertai } & \text { kecemasan } \\
\text { sosial, 5\% } & \text { kecemasan } \\
\text { panik disertai kecemasan } \\
\text { obsesif, 7\% } & \text { kecemasan } \\
\text { sosial disertai obsesif, 1\% } \\
\text { kecemasan } & \text { umum } \\
\text { disertai } & \text { dengan } \\
\text { kecemasan } & \text { panik dan } \\
\text { kecemasan } & \text { sosial, } 0 \%\end{array}$ \\
\hline
\end{tabular}




\begin{tabular}{|c|c|c|c|c|c|c|c|c|c|}
\hline No & Penulis & Judul Artikel & Negara & Tujuan & Desain & Sampel & Prosedur & Aspek Mental & Hasil \\
\hline & & & & & & & & & $\begin{array}{lr}\text { kecemasan umum } & \text { umuar } \\
\text { disertai kecemasan panik } \\
\text { dan obsesif, } 4 \% \\
\text { kecemasan umum } \\
\text { disertai kecemasan sosial } \\
\text { dan obsesif, } 17 \% \\
\text { kecemasan panik disertai } \\
\text { kecemasan sosial dan } \\
\text { obsesif, serta persentase } \\
\text { tertinggi } 18 \% \text { kecemasan } \\
\text { umum disertai } \\
\text { kecemasan panik, } \\
\text { kecemasan sosial, dan } \\
\text { kecemasan obsesif. }\end{array}$ \\
\hline 5. & $\begin{array}{l}\text { E. Andiarna, } \\
\text { Funsu; } \\
\text { Kusumawati } \\
(2020)\end{array}$ & $\begin{array}{l}\text { Effects of } \\
\text { Online } \\
\text { Learning on } \\
\text { Student } \\
\text { Academic } \\
\text { Stress During } \\
\text { the Covid-19 } \\
\text { Pandemic }\end{array}$ & Indonesia & $\begin{array}{l}\text { Mengetahui } \\
\text { pengaruh } \\
\text { pembelajaran } \\
\text { daring terhadap } \\
\text { stres akademik } \\
\text { mahasiswa selama } \\
\text { pandemi Covid- } \\
19 .\end{array}$ & $\begin{array}{l}\text { Cross } \\
\text { Sectional }\end{array}$ & $\begin{array}{l}\mathrm{N}=285 \\
\text { Mahasiswa } \\
\text { S1 Pulau } \\
\text { Jawa }\end{array}$ & $\begin{array}{ll}- & \text { Mengisi kuisioner } \\
- & \text { Uji a analisis } \\
& \text { regresi logistic }\end{array}$ & Stress & $\begin{array}{lr}\text { Pembelajaran } & \text { daring } \\
\text { mempengaruhi } & \text { stress } \\
\text { akademik } & \text { selama } \\
\text { pandemi Covid-19 }\end{array}$ \\
\hline 6. & $\begin{array}{l}\text { Courtney et al. } \\
\text { (2020) }\end{array}$ & $\begin{array}{l}\text { COVID-19 } \\
\text { Impacts on } \\
\text { Child and } \\
\text { Youth } \\
\text { Anxiety and } \\
\text { Depression: } \\
\text { Challenges } \\
\text { and } \\
\text { Opportunities }\end{array}$ & & $\begin{array}{l}\text { Mengetahui } \\
\text { dampak Covid-19 } \\
\text { terhadap } \\
\text { kesehatan mental } \\
\text { anak dan remaja } \\
\text { terrkait dengan } \\
\text { fokus terhadap } \\
\text { gejala depresi dan } \\
\text { anxiety }\end{array}$ & - & -- & $\begin{array}{l}\text { Informasi diperoleh dari } \\
\text { artikel tentang Covid-19 } \\
\text { dan dampaknya, serta } \\
\text { informasi } \\
\text { Departemen Psikiatri dan } \\
\text { Pusat Kesehatan Mental } \\
\text { Toronto Kana }\end{array}$ & $\begin{array}{l}\text { Kecemasan } \\
\text { dan Depresi }\end{array}$ & $\begin{array}{lr}\text { Pandemi } & \text { Covid-19 } \\
\text { berdampak } & \text { pada } \\
\text { kecemasan } & \text { dan stress } \\
\text { pada } & \text { anak-anak } \\
\text { merupakan } & \text { suatu } \\
\text { tantangan } & \text { baru bagi } \\
\text { psikiater di seluruh dunia } \\
\text { dalam } & \text { menghadapi } \\
\text { pandemi } & \text { Covid-19 di } \\
\text { bidang kesehatan mental. }\end{array}$ \\
\hline 7. & $\begin{array}{l}\text { Cucinotta \& } \\
\text { Vanelli }(2020)\end{array}$ & $\begin{array}{l}\text { WHO } \\
\text { declares }\end{array}$ & & $\begin{array}{l}\text { Mengetahui } \\
\text { informasi garis } \\
\text { besar Covid-19 }\end{array}$ & - & - & $\begin{array}{l}\text { Prosedur penelitian } \\
\text { dilakukan dengan studi } \\
\text { literatur terkait Covid-19 }\end{array}$ & Anxiety & $\begin{array}{lr}\text { Pandemi } & \text { Covid-19 } \\
\text { muncul pertama kali di } \\
\text { Negara Cina dengan }\end{array}$ \\
\hline
\end{tabular}




\begin{tabular}{|c|c|c|c|c|c|c|c|c|c|}
\hline No & Penulis & Judul Artikel & Negara & Tujuan & Desain & Sampel & Prosedur & Aspek Mental & Hasil \\
\hline & & $\begin{array}{l}\text { COVID-19 a } \\
\text { pandemic }\end{array}$ & & $\begin{array}{l}\text { sebagai pandemi } \\
\text { di seluruh dunia }\end{array}$ & & & $\begin{array}{l}\text { dengan menggunakan data } \\
\text { dari seluruh dunia. }\end{array}$ & & $\begin{array}{l}\text { penyebaran yang sangat } \\
\text { cepat hingga menjadi } \\
\text { pandemi di Seluruh } \\
\text { dunia. Covid-19 menjadi } \\
\text { tantangan baru bagi para } \\
\text { tenaga kesehatan dalam } \\
\text { menekan penularan } \\
\text { Covid-19. Gejala Covid- } \\
19 \text { yang umum dengan } \\
\text { gejala penyakit ringan } \\
\text { menyulitkan masyarakat } \\
\text { untuk identifikasi } \\
\text { mandiri, kecuali individu } \\
\text { dengan penyakit akut } \\
\text { yang mana dapat } \\
\text { menimbulkan kematian. }\end{array}$ \\
\hline
\end{tabular}

